\title{
Mersin Folklorunda Püse (Kara Hekim) İle İlgili Tespitler
}

\author{
Mehmet Alptekin* \\ Kilis 7 Aralı Üniversitesi \\ Fen-Edebiyat Fakültesi \\ orcid.org/0000-0003-2387-2576
}

\begin{abstract}
$\ddot{O} z$
Mersin; doğuda Adana, kuzeyde Konya ve Karaman, batıda Antalya ile komşu olup güneyde Akdeniz sahil şeridiyle çevrilidir. Mersin'in yerli halkın büyük ölçüde Oğuzların Sarıkeçili, Karakeçili, Boynu İnceli, Ceritli, Avşar, Menemenci ve Tekeli Türkmenleri oluşturmaktadır. Mersin, bu sebeple Orta Asya'yla benzer kültürel değerlere sahip bir yerleşim yeridir. Güney sınırın Akdeniz'in oluşturduğu Mersin, bitki örtüsü açısından önemli bir çeşitliliğe sahiptir. Bu bitkiler içerisinde çam ağaçları en dikkat çekenidir. Bu çalışmada; temiz hava, bol oksijen kaynăğ, hayvanların barınak yeri ve insanların ısınma kaynă̆ı olan çam ağaçlarının kuruyan çıralı kısımlarından elde edilen püse (kara hekim) hakkında tespitler sunulmuştur. Püse; geçmişten günümüze kadar ulaşan önemli kültürel öğelerimiz arasındadır. Bu sebeple konu; püsenin elde edilişi, halk sağhl̆ğı, geçiş dönemleri, halk inançları ve söz varlığındaki yeri olmak üzere beş ana başlık altında değerlendirilmiştir. Çalışmadaki veriler görüşme yöntemi ve doküman incelemesiyle elde edilmiş olup kültür analizi yöntemiyle incelenmiştir. Bu sayede, bir dönem kültür hayatının önemli unsurları arasında olan püsenin Mersin folklorundaki önemine de dikkat çekilmeye çalışılmıştır.
\end{abstract}

Anahtar Kelimeler: Mersin, kültür, püse.

\section{Designation of the Püse (Kara Hekim) in the Folklore of Mersin}

\section{Abstract}

Mersin is surrounded by Adana in the east, Konya and Karaman in the north, Antalya in the west and the Mediterranean coast in the south. The residents of Mersin are mostly composed of Sarıkeçili, Karakeçili, Boynu Inceli, Ceritli, Avşar, Menemenci and Tekeli Turkmens. For this reason, Mersin is a settlement having similar cultural values with Central Asia. Mersin, where the southern border is formed by the Mediterranean Sea, has an important diversity in terms of vegetation. Among these plants, pine trees are the most striking ones. In this study, evaluations on püse (kara hekim) that obtained from the dry branches of pine trees which are the sources of fresh air and abundant oxygen, used for heating and as an animal shelter are presented. Püse; from past to present is among our important cultural elements. For this reason; this study was evaluated on five main dimensions: the acquisition of püse, public health, transition periods, beliefs of the people and the place in the vocabulary. The data were obtained using interview method and document analysis and analyzed by culture analysis method. Thus, it was attempted to draw attention to the importance of püse in Mersin folklore which is one of the important elements of cultural life.

Keywords: Mersin, culture, püse.

\section{Giriş}

İnsanlar, tarihin ilk dönemlerinden beri atlı-göçebe hayat tarzına bağlı olarak doğa ile iç içe olmuş, günlük hayatlarını buna göre şekillendirmişlerdir. Doğa ile barışık bir hayat süren insanoğlu, doğanın kendilerine sunduğu iyilikleri unutmamış ve doğayı "anne" olarak kabul etmişlerdir. Bu durum Türkler için de geçerlidir. 
Doğa ile iç içe hayat süren Türkler, zamanla her şeyde olduğu gibi çeşitli hastalıkların tedavisinde de doğaya başvurmuştur. Doğadaki bitkilerden çeşitli şekillerde ilaçlar elde ederek hastalık tedavisinde bunları uygulamışlardır. Günümüzde alternatif tıp olarak geçen bu uygulamalar elbette ki, modern tıbbın temellerini oluşturmaktadır. İnsanların hayvanları ehlileştirmesiyle birlikte halk baytarlığı ortaya çıkmış ve hayvanları sağaltma yöntemlerinde yine doğadaki bitkilerden faydalanmışlardır. Doğadaki bitkilerden ilaç yapılması anlık bir durum olmayıp elbette uzun tecrübeler sonucunda elde edilmektedir.

Orta Toroslar üzerinde yer alan Mersin'de birçok yayla, otlak ve meranın bulunması, yüksek rakımı, Asya tipi yaşam koşullarına elverişli olması; buranın 11 . yüzyıldan itibaren Anadolu'ya gelen Türkmenlerin başlıca yaşama alanı olmasına vesile olmuştur. Bu bölgeye yerleşen Türkmenler yani Yörükler konargöçer yaşam tarzı benimseyip göçerlik ile yerleşik hayat arasında bir ara yaşam tarzına sahiptirler. Yarı göçer yarı yerleşik bir yaşam tarzı benimseyen konargöçerler yaşamlarını devam ettirmek ve sağlıklarını korumak için gerekli unsurları doğadaki bitkilerden temin etmişlerdir.

Toroslarda yaşayan konargöçerlerin ilaç yapımında kullandıkları bitkilerden biri de çam ağaçlarıdır. İlk düşünüldüğünde "Çam ağacından insanlar hangi tür ilaçları yapmışlardır?" diye sorabiliriz. Ancak yaşamlarını hayvancılıkla devam ettiren insanlar için belki de doğanın onlara verdiği en büyük hediyelerinden biri çam ağaçlardır. Hem kendilerinin hem de yetiştirdikleri hayvanlarının tedavisinde büyük çapta bu ağaçlardan faydalanmışlardır. Öyle ki halk arasında çam ağacını reçinesinden elde edilen püseye "kara hekim" adı bile verilmiştir.

Halk arasında daha çok "püse/ pise/ katran" adlarıyla bilinen halk hekimliği mucizesi olan "kara hekim"in başlangıçtan beri Türk kültür hayatında önemli bir yer teşkil ettiği görülmektedir. Püse, ilk Türkçe sözlüğümüz olan Divan-ü Lügat-it Türk'te de yer almaktadır. Divan-ü Lügat-it Türk'te ağaç özü, yıgaç özü şeklinde de izah edilen püse, hurma ağaçlarının başında peyda olan hurma göbeği denen ve tadı süte benzeyen (Atalay, 1985: 46) sıvı olarak ifade edilmektedir.

Çalışmanın amacl; başta halk hekimliği ve baytarlığında karşımıza çıkan püsenin yapım aşamasından başlanarak değişik uygulamalardaki yerini ve önemini Mersin folklorundan tespit etmektir.

Çalışmanın yöntemi; çalışmadaki veriler görüşme yöntemi ve doküman incelemesiyle elde edilmiştir. Elde edilen veriler kültür analizi yöntemiyle incelenmiştir.

Çalışmanın sonucunda, bir dönem göçebe kültür hayatının önemli unsurlarından olan püsenin Türk kültüründeki önemine de dikkat çekilmeye çalışılmıştır. 


\section{Püsenin Elde Edilişi}

\subsection{Hazırlık Aşaması}

Püsenin ham maddesi çam ağacıdır. Püse, çam ağacının gövdesindeki çıra ${ }^{1} d a n$ elde edilmektedir. Bunun için ağacın gövdesinden çıkarılan çıranın kalitesi önemlidir. Bu çıralar, genellikle büyük çam ağaçlarının gövdesinden elde edilmektedir. Bu ağaç, kuru olup özünü tutmuş olması gerekmektedir. Bu nedenle ağacın kuruduktan sonra yaklaşık iki sene beklemiş olması uygun görülür.

Mersin ve yöresinde püse, genel olarak çam ağacından elde edilen sıvılar için kullanılmaktadır. Benzer özelliklere sahip katran ise ardıç ağacından elde edilmektedir. Toros Dağları'nın kuzeydoğu uzantısını oluşturan Binboğa Dağları'nda yaşayan konargöçerler arasında da katran kamalak ${ }^{2}$ ağacından elde edilen maddeler için kullanılmaktadır. Öyle ki Ali Rıza Yalgın, Binboğa'da katran yapımında "kamalak" ağacının önemine dikkat çekerken çam ağacına da değinmektedir. "Dağların kadısı kamalak, müftüsü çamdır." (Yalgın, 1977: 175).

Mersin-Silifke konargöçerlerinin günlük yaşamında püse önemli bir yer teşkil ettiği için püsenin yapım aşaması da önemlidir. Püse havuzu, büyük bir sayın (taş) meyilli yamacına yapılır. Taşın üzeri leğen şeklinde çamurla oval olarak sıvanır. Sıvama işleminde kullanılan çamur genellikle killi topraktan elde edilir.

Püse yapımı için hazırlanan yer, görüntü itibarıla büyük bir leğeni andırmaktadır. Buraya püse havuzu ya da "püse şıranası" adı verilir. Ayrıca bu havuzun meyilli kısmında biriken suyun akması için "şırana" adı verilen meyilli bir oluk/akma yeri de vardır. Burada biriken püselerin kaba akması sağlanır (KK. 1, KK. 2).

Tarsus'un Sandal köyü ile Kadirli'nin Tahta köyünde püsenin ikinci bir yapım şeklinin de olduğunu görüyoruz. Her iki yerde de püse yere açılan ocağın haricinde, çıraların teneke içine yerleştirilmesiyle elde edilebilmektedir (KK. 4).

\subsection{Yapım Aşaması}

Silifke'de çam ağacının gövdesindeki çıralar küçük parçalar hâlinde püse havuzuna yerleştirilir. Çıraların boyutu $30-40 \mathrm{~cm}$ arasında değişmektedir. Çıra parçaları, havuzun içerisine dikey olarak bırakılır. Bu çıraların üstü taze çam pürleriyle kaplanır. Daha sonra pürlerin üzeri de toprak ile sıvanarak kapatılır. Püse havuzunun üzerine getirilen odunlar havuzun üzerini kaplayacak şekilde yerleştirilerek yakılır ve bu ateş duruma göre 2-3 gün yanar. Püsenin oluşum aşamasında ortaya çıkan ilk su bir kaba alınır. Bu suya "püse suyu" denir. Bu su ile genellikle göveğen adı verilen sineğe karşı deveyi korumak için kullanılır. Püse havuzundan akan sıvı madde, zeytinyağından daha koyu bir hâle gelmesiyle püsenin esas kıvama geldiği anlaşılır. Bu madde daha sonra birçok amaçla özellikle hayvan ve insanların tedavi sürecinde kullanilır.

\footnotetext{
${ }^{1}$ Çıra: Çam vb. reçineli ağaçların yağlı ve yanmaya elverişli bölümü.

${ }^{2}$ Kamalak: Adana ve civar yerleşim yerlerinde sedir ağacına verilen isimdir.
} 
Püse yapımında, havuzun üzerindeki ateşin içerideki çıralara ilişmemesi (tutuşmaması) için bir kişi ateşin başında 2-3 gün bekler. En sonunda ise artık püsenin akması durunca püse ocağı bozularak havuzun içerisindeki çıralar da yakılır. Püse, tenekelere doldurulduktan sonra herhangi bir işlem yapılmaksızın saklanır. Püse yapıp bunun ticaretini yapan kişilere "püseci" adı verilir. Bu kişiler işin erbabı olduğu için hangi çamdan ne kadar püse çlkabileceğini tahmin etmektedir (KK. 1).

Püsenin Kadirli'nin Tahta köyündeki yapım şekli ise şöyledir:

Tahta köyünün Taraklık Mahallesi'nde yaşayan ve püsecilik yapan 78 yaşındaki Nuri Yağız, sarı ve kara olmak üzere iki türlü püsenin olduğunu ifade etmektedir. Sarı püsenin kamalaktan (katran ağacı) yapılıp adının daha çok katran adıyla bilindiğine; kara püsenin ise çamdan yapıldığına dikkat çekmektedir. Nuri Yağız, sarı püsenin kara püseden daha iyi olduğuna değinmekle birlikte püsenin ocak veya teneke vasıtasıyla iki şekilde elde edildiğini belirtmektedir:

Ocak yapmak için yamaç bir yere huni biçiminde bir çukur kazılır. Bu çukurun büyüklüğü püsesi çıkarılacak çıranın miktarına göre ayarlanır. Çukur kazıldıktan sonra içi güzelce killi toprak çamuruyla sıvanır. Ocağın huni gibi olan alt kısmına bir oluk, oluğun altına da bir kap konur (KK. 5).

Püse çıkaracak kişi, omuzuna bir heybe alarak ormanın içine çıra toplamaya gider. Çamların gövdelerinde bulunan "ballı budak" denilen çıralı kuru dalları keser. Ballı budakları heybenin boyuna göre keserek ocağın olduğu yere getirir. Bu dalların içinin rengi bal rengidir. Ağacın gövdesinde kendiliğinden kurumuş bu dallara içinin renklerinden dolayı "ballı budak" denir. İstenilen kadar çıra topladıktan sonra toplanan dallar parmak kalınlığında yarılır. Bunlar ocağın içine aşağıdan yukarıya birbirine çatılarak dizilir. Ocak ağzına kadar çırayla doldurulduktan sonra üzeri samanla kapatılır. Samanın üzerine ateş yakılır. Böylece, bir yandan çıraların ısınarak sakızlarının akması, diğer yandan çıraların yavaş yavaş içten içe yanması sağlanır. Akan püse oluktan kaba dolar (KK. 5).

Elde edilen çıralar bir tenekenin, fıçının veya varilin içine doldurulur. Yere tekne gibi derince bir çukur kazılır. Çukurun üzerine ortası delik bir saç konur. İçine çıra doldurulan teneke sacın üzerine ters çevrilir. Bu tenekenin etrafı çamurla sıvanır. Tenekenin etrafına odun yığılarak ateş yakılır. Tenekenin içinde terleyen çıraların suyu önce sacın içine, sacın deliğinden de alttaki kaba akar. Kapla saç arasındaki mesafenin yakın olmaması gerekir. Aksi takdirde sacın 1sısından alttaki kapta biriken püse tutuşabilir."(KK. 5).

Tarsus'un Sandal köyünde de püse Nuri Yağız'ın anlattığı gibi yakılmaktadır. Meslektaşımız Cengiz Gökşen'in şahit olduğu bir püse yakma eylemi beş kilogramlık bir teneke kutuya doldurulan çıraların yukarıda anlatıldığı gibi yakılmasıyla yapılmıştır (KK. 4). 


\section{Halk Sağlığında Püse}

\subsection{Halk Hekimliğinde Püse}

Halkın olanakları bulunmadığı için ya da başka sebeplerle doktora gidemeyince veya gitmek istemeyince hastalıklarını tanılama ve sağaltma amacı ile başvurduğu yöntem ve işlemlerin tümü (Boratav, 1984: 122) halk hekimliği olarak adlandırılmaktadır. Halkın, hekimlere ulaşamadığı ve ulaşmasının zor olduğu durumlarda, halk kendi hekimlik yöntemlerini ortaya çıkarmıştır. Bu hekimlik maddelerinden biri de püsedir ki konargöçer halkın hayatında özellikle de sağlık alanında kullanılmasından ötürü "kara hekim" olarak bilinmektedir. Mersin halk kültüründe ilk dönemlerde olduğu gibi hâlen çeşitli hastalıkların tedavisinde püseden faydalanılmaktadır.

Mersin ve yöresinde püsenin halk hekimliğinde kullanım yerleriyle ilgili tespitler şunlardır:

\section{Ağriyan yerlerin tedavisi}

Mut'ta kabakulak hastalığı sırasında hastalığın verdiği ağrıyı hafifletmek için püseden faydalanılmaktadır. Hastanın boynunda şişen yerlere tuz ve püseden oluşan karışım sürülerek şişen yerin üzeri deve yünü ile sarılmaktadır (Atlay, 1990: 23). Deve yünü bölgeyi sıcak tuttuğu gibi püse de yakıcılık özelliği sayesinde derinin altına temas ederek ağrıyı kırmaktadır (KK. 1).

Tarsus'un dağ köylerinde kulak ağrısını durdurmak için yapılan uygulamalardan biri de pamuğun üzerine püse damlatıp ağrılı kısmın üzerine koymaktır (Öger, 2003: 344). Benzer bir uygulama Aydın'da görülmektedir. Kulakta ağrı olması durumunda katranla (püse) zeytinyağı karıştırılarak pamukla kulağın üzerine konur (Ülger, 2013: 76).

Mersin'de püsenin kullanım alanlarından biri de karın ağrısı tedavisidir. Tütün ve ezilmiş ardıç tohumu püse ile karıştırılıp oyulan bir soğan içerisine konularak toprağa gömülür ve gerektiğinde topraktan çıkarılarak tedavi amacıyla kullanılır (Ak, 2017: 396). Püsenin derinin altındaki ağrıyan yerlere etki ettiğine inanılmaktadır (KK. $3)$.

Soğuk havalarda bademciklerin şişmesi sonucunda boğazda meydana gelen ağrılara (boğaz inmesi) karşı Silifke'de püse kullanılır. Bademcik şişliğinin olduğu kısım püseyle ovulduktan sonra bir tülbent ile sıkıca sarılır. Sargı üç gün boyunca açılmaz. Püsenin verdiği ısının bademcikleri tedavi edeceğine inanılır (KK. 1). Boğaz ağrısının tedavisiyle ilgili benzer bir uygulama Antalya' da görülmektedir. Gazipaşa' da boğaz ağrisı tedavisinde, çam püsesi (kara hekim) bir bezin üstüne incecik sürülür. Bunun üstüne de bal konur ve koyun veya deve yünü ile birlikte boğaza bağlanır (Uysal, 2008: 169).

\section{Basur tedavisi}

Basur (mayasıl) olan hastanın tedavi sürecinde; bir kiremitin üzerine püse dökülerek üstü kâğıt ile örtülür. Daha sonra hasta bunun üzerine oturur (Öger, 2003: 
344). Kiremitin üzerindeki püsenin buharının mayasıllı bölgeyi tedavi edeceğine inanılmaktadır. Bunun yanında bir miktar pamuk püseye batırılarak mayasıllı kısımda bekletilir (KK. 1).

\section{Böcek 1sırması veya sokması tedavisi}

“Katran geleneksel olarak antihistaminik, antiseptik ve antimikrobiyal işlevleri ile hayvanların yaralanan yerlerinin tedavisi, haşerelerin kovulması, yılan akrep gibi sürüngenler ile kene vb. hayvanların uzak tutulması amacıyla kullanılmaktadır." (milliyet.com.tr, 2019).

Hayvancılıkla uğraşan halkın problemleri arasında keneler önemli yer teşkil etmektedir. Keneler hem insanlara hem de hayvanlara musallat olup ölümle sonuçlanacak vakalara neden olmaktadır. Keneye karşı kullanılan yöntemlerden biri de kenenin üzerine püse sürmektir. İnsan ve hayvanların vücudundan kan emdiği tespit edilen kenenin üzerine bir miktar püse damlatılır. Böylece kene ya ölür ya da bulunduğu yerden uzaklaşır (KK. 1). Püsede kenenin hoşlanmadığı bir maddenin olduğu söylenmektedir.

Antibiyotik özelliği olduğu söylenen püse ayrıca böcek 1sırması gerçekleşen bölge için de kullanılmaktadır. Erdemli'de arı sokması durumunda şiş bölge sabunlu suyla temizlenip sonrasında püse sürülür (Kırmızı, 2015: 158).

Püsenin etrafa yaydığı kokunun böceklerin hoşuna gitmemesinden ötürü çeşitli böceklerin istilasına karşı da püse kullanılmaktadır. Mut'ta, karınca istilasına uğrayan bir eşya, etrafına püse akıtılarak önlem alınmaktadır (Atlay, 1990: 24).

Silifke'de ağaçtan yapılmış ev eşyalara tahtakurusunun ve diğer haşerelerin gelmesini önlemek için püse kullanılır. Püse, bu haşereleri öldürmez ancak sürüldüğü bölgeden uzak tutar. Bu sayede insanlar bu haşerelerden korunmuş olur hem de evdeki ağaçtan yapılan eşyalarına bu haşerelerin zarar vermesi önlenmiş olur (KK. 1).

\section{Deri hastalıklarının tedavisi}

Vücutta şişlik ve kızarıklarla kendini belli eden egzamanın genetik ve çevresel faktörler gibi birçok sebebi söz konusudur. Bir deri hastalığı olmasından ötürü halk hekimliğinde genellikle çeşitli maddelerden elde edilen karşımlar sürülür. Mut'ta; egzama tedavisinde püse, tuzsuz inek yağı ve yumurta sarısı karıştırılıp pomat yapılarak her gün egzamalı bölgeye tatbik edilir (Atlay, 1990: 24).

Parmak iltihaplanması olarak da bilinen dolama hastalığının tedavisinde de püseden yararlanılmaktadır. Dolama olan parmaktaki iltihaplı yer sıcak su ile iyice temizlendikten sonra iltihaplı kısma püse sürülür. Püse yaranın olduğu kısmı biraz yaksa da yara kısa süre de kendini toparlayarak iyileşir (KK. 3).

\section{İshal tedavisi}

Vücutta yoğun su kaybı şeklinde ortaya çıkan ishale karşı erken önlem alınmadığı zaman ciddi problemler ortaya çıkabilmektedir. Mut'ta, ishale karşı kuru kahveyle püse karıştırılıp nohut büyüklügünde yuvarlak tabletler yapılır. Bu nohut 
büyüklüğündeki tabletler hastaya yutturulur (Atlay, 1990: 23). Bu tabletlerdeki karışımın bağırsaktaki mikropları kıracağına ve hastanın 5-6 saat sonra iyileşeceğine inanilır (KK. 3).

Mut'ta, kurbağacık hastalığına (çocuk yaz ishali) yakalanan çocuğun karnına yağ ile karıştırılan püseyle iyice masaj yapılır. Yağlı püseye batırılmış bir kompres çocuğun karnına konarak sarılır (Atlay, 1990: 23).

\section{Solunum yolu hastalıklarının tedavisi}

Püsenin farklı bir şekli olan ardıçtan elde edilen katran da gögüs ağrısı çekenlerin tedavi de başvurdukları doğal bir yöntemdir (KK. 1). Çok sigara içmekten dolayı solunum güçlüğü çeken kimselere ardıç katranı ile baldan elde edilen karışım yedirilir. Bu karışım 10-15 gün yedirildikten sonra kişinin göğüs ağrıları iyileşir ve nefes alması kolaylaşır (KK. 1).

Solunum kaynaklı göğüs ağrılarına karşı da göğüs kafesinin üzeri püse ile iyice yağlanır. Daha sonra püseli kısmın üzeri ince bezle örtülür. Bezin örtülü olduğu kısmın üzerine ısıtılmış kiremitler yerleştirilir. Bu işlem bir hafta kadar uygulanır. Böylece göğüs ağrılarının geçeceğine ve nefes alıp vermenin kolaylaşacağına inanılır (KK. 3).

\section{Yaraların tedavisi}

Doğrudan olduğu gibi diğer nesnelerle de karşım yapılarak püse, yaraların tedavisinde kullanılmaktadır. Mut'ta; püse, soğuk suda rengi açllıncaya kadar yıkanır, biraz tuzsuz inek yağı ile karıştırılıp iyice dövülerek pomat yapılır her çeşit yara tedavisinde güvenle kullanılır (Atlay, 1990: 24).

Silifke'nin dağ köylerinde vücutta oluşan çıbanların olgunlaşması (yetirilmesi) için arpa unuyla püse karıştırılarak hamur hâline getirilip yaranın üzerine sarılır. Bir gün bekleyen yara kendiliğinden olgunlaşır (KK. 1). Benzer uygulama Adana'da söz konusu olup burada püsenin içerisine zift ve kükürt karıştırılmaktadır (Özgen, 2007: 43).

Vücutta herhangi bir darbeden dolayı şişme veya morarma olması durumunda kepek ıslanarak içine biraz tuz atılır ve şişen bölgeye sarılır. Şişen kısım jiletle kesilerek pis kan akıtılır daha sonra koyunun kuyruk yağıyla kuru üzüm dövülerek kesilen kısmın üzerine sarılır. İçine püse konmuş hamur veya soğan pişirilerek şişen kısma sarılır (Öger, 2003: 345). Püseli hamur yaranın mikrop kapmasını önlemektedir. Gazipaşa'da, berelenme ve ezilmede ise soğan, püse, un tavada 1sitılır ve hamur kıvamına gelinceye kadar karıştırılır. Elde edilen karışım, sıcaklığı tamamen kaybolmadan ezilen bölgeye sarılır (Uysal, 2008: 162).

\subsection{Halk Baytarlığında Püse}

İnsanların yerleşik yaşama geçmesiyle birlikte yaşamlarının bir parçası olan hayvanların tedavisinde başlangıçtan beri halk baytarlığı önemli bir yere sahiptir. Öyle ki değişen yaşam şartlarıyla birlikte baytarlık müstakil bir bilim hâline dönüşüp hâlen kırsal kesimlerde halk baytarlığı uygulamaları da devam etmektedir. 
Yörüklerin uğraş alanı içerisinde hayvancılık önemli bir yer tutar. Hayvancılıkla uğraşan halk besledikleri hayvanlarını bazen evin bir bireyi kabul edip onlarla her yönüyle ilgilenmişlerdir. Onların doğumlarından isim almalarına ${ }^{3}$, çiftleştirilmesinden hastalıklarının tedavi edilmesine her konuda zengin kültürel birikim meydana getirmişlerdir.

Besledikleri hayvanlarda görülen hastalıkları geleneksel olarak teşhis eden Yörüklerde zengin bir halk baytarlığı bilinci bulunduğu gibi hayvanları bitki ve hayvan kaynaklı ürünler yanında çeşitli yöntemlerle tedavi ederler ve gerekli koruyucu tedbirleri de alırlar (Ak, 2017: 52). Mersin Yörüklerinde bu tedbirlerden biri de "kara hekim" olarak adlandırılan püsedir. Püsenin Mersin halk kültürü baytarlığında kullanım alanları şu şekilde karşımıza çıkmaktadır:

\section{Böcek 1sırması veya sokması tedavisi}

Develerin yaz aylarında üzerlerindeki tüyleri dökülür. Bu durumda deveye güveğen sineği musallat olur ve onu rahatsız eder. Devenin tüyünün dökülen yerlerine püse sürülerek güveğen gelmesi engellenir (KK. 2). Gazipaşa'da güveğen sineğinden farklı olarak bügelek adı verilen daha çok büyükbaş hayvanların üzerlerine yapışarak, hayvanların kanını emen ve hayvanı rahatsız eden bir sinek türü vardır. Hayvanı bu sinekten korumak için, hayvanın üzerine katran veya püse sürülür (Uysal, 2008: 179).

\section{Deri hastalıklarının tedavisi}

Hayvanlarda yaygın görülen deri hastalıklarının başında uyuz gelmektedir. Uyuzun tedavisinde halk baytarlığında püse karşımıza çıkmaktadır. Öyle ki bu durum halk anlatılarına da yansımıştır ${ }^{4}$. Nasreddin Hoca'ya uyuz olan keçisini tedavi etmesi için gelen köylüye Nasreddin Hoca püsenin (katran) önemini kısaca şu şekilde özetlemektedir: Köylünün biri, uyuz keçisini Hoca'ya getirmiş. “Nefesin keskindir, bir okuyuver Hocam." demiş. Hoca da "Nefesim keskindir amma katransız tesir etmez. Ben nefes edeyim, sen de nefesime biraz katran ekle, keçiye sür." demiş. (Gölpınarlı, 1993: 30).

Mut'ta da uyuz hastalığına yakalanan hayvanların tedavisinde yağlı püse kullanılmaktadır (Atlay, 1990: 24). “Koyun, keçi, eşek ve köpeklerde görülen uyuz hastalığında hayvanın tüyü dökülür, sürekli kaşınır ve deri üzerinde yaralar oluşur. Uyuz olan hayvan sarı püse ile yağlanıp tedavi edilmeye çalışılır." (Seyirci, 2000: 189; Çabuk, 2008: 182; Ak, 2013: 41). Gazipaşa' da hayvanlarda görülen uyuz hastalığının da tedavisinde püseden yararlanıldığı görülmektedir. Uyuz olan hayvan ilk önce güzelce yıkanır. Daha sonra püse ile yă̆ karıştırılarak bir kabın içerisinde kaynatılır. Kaynatılan sıvı, yakıcılığı geçtikten sonra, hafif sıcak hâldeyken, hayvanın uyuz olan bölgelerine sürülür (Uysal, 2008: 180). Düziçi'nde uyuz hastalığını tedavi etmek için

\footnotetext{
${ }^{3}$ Toroslarda yaşayan konargöçer halkın yaşamında keçiler önemli yer tutar. Keçi yetiştiriciliği ve bu alandaki uygulamalarla ile ilgili olarak bkz: Gökşen, C. (2007). Sandal Köyü Tarsus ve Çevresinde Keçilere Verilen Adlar ve Davarcılıkla İlgili Bazı Uygulamalar, Milli Folklor, 19 (76): 134-148.

${ }^{4}$ Bu konuda ayrıntılı olarak bkz: Dağı, F. (2013). Türk Halk Anlatılarında Halk Hekimliği Üzerine Bir Araştırma (Basılmamış Doktora Tezi). Balıkesir: Balıkesir Üniversitesi Sosyal Bilimler Enstitüsü.
} 
kamalak ağacından elde edilen sarı katran, hastanın uyuz olan yerlerine sürülür. Bu katran o bölgede bulunan biti de öldürür (Kurum, 2008: 28).

Çamurlu ve islak yerlerde çokça gezdirilen koyunlarda görülen çatalaksak hastalığında koyunun ayaklarının arasında sulu yaralar belirirken fazla kayba yol açmaz ancak hayvanı oldukça zayıflatır. Bu sulu yaralar nedeniyle koyunun ayağına kurt düşmemesi için tırnak aralarında oluşan yaranın üzeri su ile yıkanıp temizlendikten sonra püselenerek tedavi edilmeye çalışılır (Güngör, 1941: 37; Ak, 2013: 41).

\section{Şap tedavisi}

"Yörükler arasında genellikle tabak hastalığı olarak bilinen şap hastalığı deve, koyun, keçi ve sığır gibi çift tırnaklı hayvanlarda görülen bir hastalık olup hayvanın tırnaklarının arasında ve ağzında yaralar oluşur." (Seyirci, 2000: 191; Çabuk, 2008: 182; Gönüllü, 2004: 296). Bu nedenle hayvan yere basamaz, sürü ile dolaşamaz ve otlayamaz. Böylece bir şey yiyemeyen hayvan zayıflar Mersin'de hayvanların tırnaklarının arasında çıkan yaralara "tabak" adı verilir. Bu durumdaki hayvan ayağının üzerine basamaz. İyileşmesi için yaranın üzerine limon sıkılır, yağ ya da çam püsesi sürülür (Bali, 2015: 375).

Erdemli 'de hayvanların tırnaklarda oluşan dolama hastalığının tedavisinde de püse kullanılır (Kırmızı, 2015: 156). Benzer uygulamalar Antalya’ da da vardır (Gönenç, 2011: 76).

\section{Kirık tedavisi}

Erdemli 'de koyun, keçi gibi hayvanların ayağı kırıldığı zaman, kırılan bacak genelde ince tahta parçalarıyla sarılır. Tahtaların etrafı da kaymayı önlemek için keçeyle (kepenek) sarılır. Bu yönteme yörede "seyikleme" adı verilir. Kırılan ayağa püse sürülür. Püse hem kırık bacağa gelecek sinekleri uzaklaştırır hem de doğal bir antibiyotik özelliği gösterir. Hayvanın ayağı bu yöntemle yaklaşık on gün sarılı kaldığında tedavi süreci tamamlanmış olur (Kırmızı, 2015: 163).

\section{K1l kurdu tedavisi}

Kıl kurdu koyun ve keçi hastalığı olup hayvanın yeterli beslenememesinden ve soğukta kalıp üşümesinden kaynaklanır. Kıl kurdu hastalığına yakalanan hayvanın gırtlağında ve akciğerinde kurtçuklar teşekkül eder ve bundan dolayı hayvan zayıflayarak devamlı öksürür (Ak, 2017: 55). Koyun ve keçilerin bağırsaklarına kıl kurdu musallat olduğu zaman hayvanları çok zayıflatır. Kıl kurdu tedavisinde hayvanların su, yem ve tuzuna püse karıştırılarak yemesi sağlanır. Hayvanlar bu yiyecekleri yiyince püse hayvanın bağırsağındaki parazitleri temizler (KK. 1).

Kuzu ve oğlakların sıcak dönemlerde aşırı süt emmesinden kaynaklandığı düşünülen öyken hastalığında hayvan sürekli öksürür. Mut çevresindeki Sarıkeçili Yörükleri, öyken hastalığına tutulan oğlaklar için püse ile şapı karıştırıp nohut büyüklüğünde yuvarlak hâline getirir ve oğlağa yuttururlar. Bu işlemden sonra eğer 
oğlak ötürürse tedavi edilir ki muhtemelen püse ve şap karışımı bağırsaklardaki paraziti temizler (Dulkadir, 1997: 160; Ak, 2017: 54).

Davarların ciğerlerinde kelebek hastalığı olduğunda hayvanlar sürekli öksürür. "Püse malası" adı verilen yassı ekmek şişine benzeyen ucu bezle kaplı çubuk püse çanağına batırıldıktan sonra hayvanın boğazına zorla da olsa sokulur. Püseyi yemek istemeyen hayvan bunu yutmuş olur ve tedavi gerçekleşir (KK. 1, KK. 2). Zayıf olan hayvana katran yalatıldığı zaman hayvanın iştahı açılır ve karaciğer temizlenir (Kurum, 2008: 84).

\section{Soğuk algınlığı tedavisi}

Hayvanların terleyip soğumaları sonucunda ortaya çıkan sangırılama (soğuklama) tedavi edilmezse hayvanın halsizleşip ölmesine neden olmaktadır. Soğuk algınlığı olan (sangırılayan) hayvanların burnu püseyle iyice ovulup kızgın şiş ile dağlanır (KK. 1). Püsenin hayvanın burnunu yaktığı ve bu yakma sayesinde soğuk algınlı̆̆ını geçirdiğine inanılmaktadır.

\section{Yaraların tedavisi}

Hayvanların vücutlarında meydana gelen yaralar mikrop kapmaya meyillidir. Bunu için yaranın bulunduğu kısma çeşitli uygulamalar yapılarak mikrop kapması engellenmeye çalışılır.

Silifke'de iş hayvanlarının boyunları bazen boyunduruk tarafından vurularak yağır (yara) olur. Bu tür yaraların geçmesi çok zordur. Yağır olan kısma iç yağı ile püse karıştırılarak sürülür (KK. 2). Böylece hem yara mikrop kapmaz hem de yara kısa sürede iyileşir. Benzer uygulama Tarsus'ta da karşımıza çıkmaktadır. At, eşek veya katırların semer (palan) vurması sonucu sırtlarında oluşan yağırların (yaraların) iyileşmesi için püse sürülür (KK. 4).

Tarsus'ta yaz gününde yaralanan hayvanların yaralarının iyileşmesi ve özellikle sineklerin kurt atmaması için püse sürülür (KK. 4).

Mut'ta atların ayaklarına olan bıçılgan (akıntılı bir yara) hastalığının tedavisinde püse kullanilır (Atlay, 1990: 24).

Mut'ta keçilerin ağzında "eski" denen kuru, kabuklu bir yara oluşur. Bu hastalığın tedavisinde de püse kullanılmaktadır (Atlay, 1990: 24).

Hayvanların çeşitli nedenle vücutlarında meydana gelen iltihaplı yaralar temizlenerek yaranın olduğu kısım pansuman yapıldıktan sonra püse ile iyice doldurulur (KK. 1).

Mersin'in dağlık yerleri engebeli coğrafi yapıya sahip olduğundan hayvanlar taşlı yerde hareket ederken ayaklarında kesikler meydana gelir. Bu durumda püse ile kül karıştırılarak merhem yapılır. Yaralı kısma elde edilen karışım sürülerek mikrop kapması engellenmeye çalışılır. Köpeğin vücudunda meydana gelen yaralara ise püse sürülmez eğer sürülürse köpeğin öleceğine inanılır (KK. 1). 


\section{Zehirlenme tedavisi}

Yanlış ot yemekten dolayı zehirlenen hayvanlara uygulanan tedavi yöntemlerinden biri de püse yutturmaktır. Püse yuttuktan sonra hayvan ishal olup midesindeki zararlı zehirleri atar. Ayrıca hayvanın arkasından da püse sürülür (KK. 1).

\section{Geçiş Dönemlerinde Püse}

Geçiş dönemi adı verilen doğum, evlilik ve ölüm insan hayatının kritik dönemlerini teşkil etmektedir. Püse, konargöçer toplumların hayatında önem teşkil etti için hayatın her döneminde de karşımıza çıkmaktadır. Mersin halk kültüründe püsenin bu dönemlerden doğum ve ölümle ilişkili kullanıldığı tespit edilmiştir.

\section{Doğum}

Mersin'de çocuk sahibi olmak isteyip de olamayan aileler birçok uygulama gerçekleştirmektedir. Bu amaç doğrultusunda kadınlar için toprağa yalak kazılır, bu yalağın içine ardıç ağacının yakılmasıyla elde edilen püsenin kaynatıldığı su dökülür ve kadın bu suyun buharına oturtulur (Bali, 2015: 170).

Bebek doğduktan sonra göbek bağından hava aldığı ve bu nedenle karnının

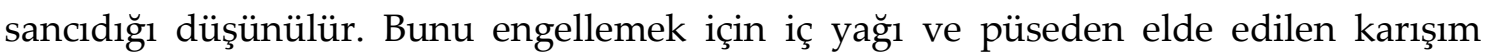
bebeğin göbeği üzerine yerleştirilir. Böylece bebeğin göbeğinden hava almayacağına ve göbeğin çabuk kaynayacağına inanılır (KK. 1).

Mut'ta, küçük bebekler ağladığı zaman kulağı sancıdığına hükmedilir, bebeğin kulağına yağlı püse akıtılır (Atlay, 1990: 23).

\section{Ölüm}

Bilinmezliklerle dolu olduğu için dünya üzerindeki bütün toplumlarda olduğu gibi Türk toplumunda da ölümle ilgili çeşitli ritüeller ortaya çıkmıştır. Bu ritüeller toplum tarafından uygulandığı zaman toplum yapısında bir memnuniyet ve rahatlama, uygulanmadığı zamanlarda ise bir sıkıntı olmaktadır.

Silifke'de, ölen kişinin mezarının hece taşına bir miktar püse dökülür. Bu uygulamadaki amaç; "sin kurdu" adı verilen kedi büyüklüğündeki bir yaratığın mezarı açmasını önlemektir. Mezar taşına püse sürülmesi durumunda bu hayvanın mezara gelemeyeceğine inanılır (KK. 1).

Mersin'deki inanışa göre; bu hayvan, kedi büyüklügünde olup taze mezarları kazarak cesedin kafasını yemektir. Bundan korunmak için Gülnar'daki mezarların üzerine halk tarafından dikenli ağaçların dalları ve büyük kayalar bırakılmaktadır (KK. 3).

Tarsus'ta, Silifke'den farklı olarak mezara gelerek açtığına inanılan canlıya "zırtlan" adı verilmektedir. "Zırtlan"ın mezarı açarak cenazeyi yememesi için de hece taşının üzerine püse bulunan bez konur. İnanca göre püsenin kokusundan dolayı bu hayvan kabre yaklaşamaz (Öger, 2003: 328-329). 


\section{Halk İnançlarında Püse}

Toplum hayatında, özellikle sağlık açısında, kendisine önemli bir yer edinen püse hakkında çeşitli inançların var olduğunu görmekteyiz. Toplum hayatında püse etrafında çeşitli inançların ortaya çıkması püsenin kültür hayatındaki yerini göstermesi açısından önemlidir.

Akşam vakti evden dişarıya püse verilmez. Eğer zorunlu bir durum olup evden dışarıya püse verilirse püsenin alındığı yere bir tutum tuz serpilir (KK. 2).

Püse ocağının yapımı öncesinde ocağın yapılacağı yere genellikle metal paradan arılık ${ }^{5}$ atılır. Böylece püsenin verimli olacağına inanılır (KK. 1).

Püse ocağı kurulurken kimsenin görmemesi sağlanır. Eğer püse hazırlama sırasında bir kişi gelirse, ocak yanarken bozulacağına inanılır (KK. 2).

Yaşar Kalafat Bey'in belirttiğine göre, ahırlarda atları kullanan üç harflileri yakalamak için de atların sırtına püse sürülür (KK. 6).

Tarsus dağ köylerinde; dünürlüğe gidildiği anda "Kız evindekilerin başı dönsün de kızlarını versin." diye oğlan evinin önüne bir ip asılır ve bir kişi o yumağı devamlı çevirir. Bunun yanı sıra oğlanın annesi eline mum veya ayağının altına püse sürer (Öger, 2003: 306).

\section{Söz Varlığımızda Püse}

Bir dilin söz varlığı denince, yalnızca o dilin sözcüklerini değil; deyimlerin, kalıplaşmış sözlerin, atasözlerinin, terimlerin ve çeşitli anlatım kalıplarının oluşturduğu bütünü anlamak gerekmektedir (Aksan, 2004: 7). Bu bölümde Mersin ve yöresinde püse ile ilgili söz varlığımıza giren kavramlar hakkında bilgi verilmiştir:

- Pardı: Püse yapımı için kesilen çıra parçaları,

- Püseci: Püse yapıp satarak hayatını devam ettiren kişi,

- Püse yalağı: Püse yapımı için hazırlanan çukur, eşik,

- Püse çanağı: Püsenin yapım aşamasında toplandığı kap,

- Püse kabağı: Evlerde veya çadırlarda püsenin içerisinde saklandığı su kabağı,

- Püse malası: Hayvanların boğazına püse dökmeye yarayan ucunda bez bulunan çubuk,

- Püse şırası: Püsenin hazırlanışı sırasında ilk çıkan sulu ve güzel kokulu kısım,

- Katran: Genellikle ardıç ağacının reçineli elde edilen siyah sıvı,

- Zift: Püseden yapılan bir maddedir. Püse teneke kutularda alevsiz ateş (köz) üzerinde kaynatılır, akide kıvamına gelince ateşten alınır. Bu karışıma zift adı verilip biraz daha katı bir yapıya sahip olup ve koy siyah bir görünümü vardır (Atlay, 1990: 23-24).

Tarsus dă̆ köylerinde; ayağının altına püse çalmak, birisinin işini engellemek anlaminda kullanılır (Öger, 2003: 270).

\footnotetext{
${ }^{5}$ Bir hastalığı ilaç veya okuyup üfleyerek geçirmeye çalışan kimseye verilen ücret, bahşiş.
} 
Silifke'de "Püse ocă̆ının yüzü karadır." derler ve bu ocağı kimsenin görmemesi sağlanır (KK. 1).

Mut'ta köyler evlerinde mutlaka bir kabak (Su kabağından özel hazırlanmış bir kap) püse bulunurdu. Püse kabakları kırılıp, dökülüp heder olmaması için evin en kuytu gözden, ayaktan rrak yerlerine konurdu. Buna göre bir de bilmece düzenlenmiş "Karanlık yerde kadı oturur: Püse kabağı." (Atlay, 1990: 23).

\section{Sonuç}

İnsanların uzun tecrübeleri sonucunda ortaya çıkardıkları ve halk sağlı̆̆ının önemli bir unsuru olan püse, ülkemizde özellikle konargöçer halkın yaygın olarak yaşadıkları kıyı şeridinde bilinmekte ve hâlen uygulama alanı bulmaktadır.

Zahmetli ve sabır isteyen bir yapım aşamasından geçen püse, doğumdan ölüme kadar hayatın her evresinde kendine yer edinmiştir. Öyle ki insanlar püseyle ilgili kendileri için uyguladıkları tedavi yöntemlerini zamanla hayvanlarına da tatbik etmişler. Hem insanların hem de hayvanların tedavisinde bir doktor gibi her yerde faydalanıldığı için püse, kara hekim adıyla da anılmaktadır.

Divanı Lügati-t Türk'te püsenin kendine yer bulması kültürel hayatımızda ne kadar eski bir geçmişinin olduğunu göstermesi açısından önemlidir.

Halk hekimliği ve baytarlığında püse, tek başına kullanıldığı gibi yardımcı bir unsur olarak da kullanılmaktadır.

Gelişen ve değişen teknolojiye rağmen hâlâ halk belleğinde püsenin unutulmaması kültürel değerlerimizin devamlılı̆̆ını sağlaması açısından önemini göstermektedir. Halk mutfağına ve halk tababetine ait birçok gidanın endüstriyel ortamda üretilmeye başlandığı günümüzde yakın bir gelecekte püsenin de endüstriyel üretimine geçilmesi muhtemeldir.

\section{Kaynakça}

Ak, M. (2013). Yörüklerin Günlük Hayatında Püse, Yörtürk, 18 (108):40-43.

Ak, M. (2017). Yörüklerde Halk Hekimliği, The Journal Of Academic Social Science Studies, (57): 395-405.

Aksan, D. (2004). Türkçenin Söz Varlı̆̆ı. Ankara: Engin Yayınevi.

Atalay, B.(1985). Divanı Lügati-t Türk I, Ankara: Kültür Bakanlığı Yayınları.

Atlay, Doğan (1990). Mut Folklorundan Damlalar (Püse-Zift-Kül), İçel Kültürü, (11): 23-24.

Bali, A. (2015). Mersin Konargöçerlerinin Halk Kültüründe İnanışlar ve Bunlara Bağlı Uygulamalar (Basılmamış Doktora Tezi). Adana: Çukurova Üniversitesi Sosyal Bilimler Enstitüsü.

Boratav, P. N. (1984). 100 Soruda Türk Folkloru (İnanışlar, Töre ve Törenler, Oyunlar). İstanbul: Gerçek Yayınevi.

Çabuk, H. H. (2008). Çukurova'da Yörükler. Adana: Ekrem Matbaası. 
Dağı, F. (2013). Türk Halk Anlatılarında Halk Hekimliği Üzerine Bir Araştırma (Basılmamış Doktora Tezi). Balıkesir: Balıkesir Üniversitesi Sosyal Bilimler Enstitüsü.

Dulkadir, H. (1997). İçel'de Son Yörükler Sarıkeçililer. Mersin: İçel Valiliği Yayınları.

Gökşen, C. (2007). Sandal Köyü Tarsus ve Çevresinde Keçilere Verilen Adlar ve Davarcıllkla İlgili Bazı Uygulamalar, Milli Folklor, 19 (76): 134-148.

Gölpınarlı, A. (1993). Nasreddin Hoca. İstanbul: Remzi Kitabevi.

Gönenç, A. (2011). Antalya İli Korkuteli İlçesinde Halk İnanışları ve Halk Hekimliği (Basılmamış Yüksek Lisans Tezi). Konya: Selçuk Üniversitesi Sosyal Bilimler Enstitüsü.

Gönüllü, A. R. (2004). Alanya Folklorunda Veteriner Hekimliği, Alanya Tarih ve Kültür Seminerleri III,Alanya: Alsav Yayınları, 296-298.

Güngör, K. (1941). Cenubî Anadolu Yürüklerinin Etno-Antropolojik Tetkiki, Ankara: Dil ve Tarih Coğrafya Fakültesi Antropoloji ve Etnoloji Enstitüsü Neşriyatı.

Kırmızı, Ö. (2015). Erdemli Halk Kültürü Araştırması (Basılmamış Yüksek Lisans Tezi). Mersin: Mersin Üniversitesi Sosyal Bilimler Enstitüsü.

Kurum, U. (2008). Düziçi'nde Halk Hekimliği (Basılmamış Yüksek Lisans Tezi). Niğde: Niğde Üniversitesi Sosyal Bilimler Enstitüsü.

Öger, A. (2003). Tarsus Yöresi Dağ Köylerinde Geleneksel Halk Kültürü Üzerine Bir İnceleme (Basılmamış Yüksek Lisans Tezi). Denizli: Pamukkale Üniversitesi Sosyal Bilimler Enstitüsü.

Özgen, Z. N. (2007). Adana (Merkez) Halk Hekimliği Araştırması (Basılmamış Yüksek Lisans Tezi). Adana: Çukurova Üniversitesi Sosyal Bilimler Enstitüsü.

Seyirci, M. (2000). Batı Akdeniz Bölgesi Yörükleri. İstanbul: Der Yayınları.

Uysal, Y. (2008). Gazipaşa'da Folklor ve Halk Edebiyatı Ürünleri (Basılmamış Yüksek Lisans Tezi). Konya: Selçuk Üniversitesi Sosyal Bilimler Enstitüsü.

Ülger, Z. (2013). Aydın (Merkez) ve Çevresinde Halk Hekimliği (Basılmamıৎ̧ Yüksek Lisans Tezi). Aydın: Adnan Menderes Üniversitesi Sosyal Bilimler Enstitüsü.

Yalgın, A. R. (1977). Cenup'ta Türkmen Oymakları II. Ankara: Kültür Bakanlığı Yayınları.

http://www.milliyet.com.tr/antibiyotik-direncine-karsi-katran-pembenar-detay-genelsaglik2164523/

\section{Kaynak Kişiler}

KK. 1: Cennet Alptekin, 1960, Silifke-İmamuşağı, Okuma-yazma yok, Ev hanımı.

KK. 2: İsmail Alptekin (Âşık İmamoğlu), 1938, Silifke-İmamuşă̆ı, İlkokul mezunu, Emekli.

KK. 3: Münevver Barı,1959, Gülnar-Kayrak, Okuma-Yazma Yok, Ev hanımı.

KK. 4: Cengiz Gökşen, 1969, Tarsus-Sandal, Yükseköğrenim, Öğretim üyesi.

KK. 5: Nuri Yağız, 1940, Kadirli-Tahta, ilkokul, Çiftçi.

KK. 6: Yaşar Kalafat, 1939, Kars, Yükseköğrenim, Öğretim üyesi 